\title{
OCCURRENCE OF PEDICULUS HUMANUS CAPITIS IN RELATION TO THEIR PERSONAL HYGIENE AND SOCIAL BEHAVIOUR AMONG THE CHILDREN IN DHAKA CITY
}

\author{
Tahmina Karim, Sharmin Musa ${ }^{1}$, Hamida Khanum and Dinesh Mondal ${ }^{*}$ \\ Department of Zoology, University of Dhaka, Dhaka 1000
}

Pediculus humanus capitis (Anoplura: Pediculidae) (De Geer 1778) or head louse is an obligate ectoparasite (Linardi et al. 1988). Head louse feeds on blood which may lead to anemia and in the scratch sites can lead to secondary infection (Slonka et al. 1976). Head lice infestation (HLI) caused by Pediculus humanus capitis, which has existed for more than 10,000 years, is a common, worldwide problem (Ha et al. 2000). It is a human parasite, which is transmitted directly by close contact with an infected individual's head or indirectly via fomites such as hair, hats, or combs (Bartels et al. 2001). Head lice feed by sucking blood and cause pruritus (itching) to host due to sensitization to louse saliva, and subsequent skin excoriation may lead to secondary bacterial infections. In addition, chronic irritation and secondary infection may disrupt behavior and school performance (Bailey and Prociv 2000).

According to Krasnov et al. (2002), for head lice, persons with close social interactions can be viewed as discrete, hierarchical nested habitat patches on different spatial scales. A patch can comprise just one host or a group of hosts defined by households, friends, class, grade, school, closely spaced schools in a municipality or whole municipalities. Habitat patch size also seems important at the household level, as several studies have found that risk of pediculosis increased with the number of members in a congested household (Willems et al. 2005, Soultana et al. 2009). Mossong et al. (2008) found that the number of daily contacts with other persons is higher for members of large households compared to small households. The objective of the study was to determine the prevalence of head louse among the children according to their sharing and cleaning habits (personal hygiene), hair type, duration of suffering and family history of pediculosis and the result of cure after application of anti-lice shampoo.

A cross sectional study was carried out during February, 2011 to January, 2012 among the children in Mirpur Bihari Camp in Mirpur 11, Dhaka. A total of 300 children aged 1 to 7 years were examined. Head louse infestation was

\footnotetext{
* Corresponding Author: sharminsumi@yahoo.com. *Scientist, Parasitology Laboratory, Laboratory Sciences Division, ICDDR,B
}

(C) 2015 Zoological Society of Bangladesh DOI: 10.3329/bjz.v43i2.27403 
identified by examining the scalp and hairs for the presence of adult lice, nymphs or viable nits in naked eyes and by using a magnifying glass or running a comb through the child's hair. The detection of lice or egg by visual examination of the child's head and their classification into "not infested" and infested was also made according to Wegner et al. (1994). A structured questionnaire was selected for data collection and a completely randomized sampling procedure was carried out for the study. The questionnaire was filled up for each child and their families through face to face interviewing. Prevalence rate was showed by calculating percentage of infestation and result was analyzed by statistical test.

A total of 300 children were examined and of them 179 were found to be infested with single species of louse, namely, Pediculus humanus capitis, so the overall prevalence was $59.67 \%$. It was observed that, 205 children are used to share bed and of them 157 child was infested with head lice and here prevalence was $76.59 \%$. Whereas 95 child were were not used to share bed and of them $22(23.16 \%)$ was infested. 170 children had the habit of cloth sharing and the rate of infestation was higher in $142(83.53 \%)$ among them. 130 children did not share their cloth and of them $28.46 \%$ was infested with head lice. It was detected that, majority of the children (217) shared their towels and $77.42 \%$ of them was infested by the head lice while $13.25 \%$ children were infested who did not share. It was found that, majority of the children (230) shared their comb and the rate of infestation was higher $(74.35 \%)$ among them. While among children those did not share comb, only $11.43 \%$ was infested. 155 children did not have the habit of bed cleaning and of them $84.52 \%$ were infested. $90(30 \%)$ study populations bathed irregularly. The rate of infestation was $87.78 \%$. On the other hand, who took their bath regularly, $47.62 \%$ was infested. The infestation rate was $80.56 \%$ among who worn the same cloth after bath. On the other hand, 120 children did not wear the same cloth after bath, among them $28.33 \%$ were infested and above all this cases difference was statistically significant $(\mathrm{p}<0.05)$ (Table 1$)$.

Pediculosis was significantly higher $(78.19 \%)$ among children with families those living in overcrowding condition than those not living in overcrowding condition $(28.57 \%)$. It was found that, most of the families $195(65 \%)$ washed their bed cloths once in a month, $60(20 \%)$ did so once in a week and $45(15 \%)$ washed their bed cloths above one month. The infestation rate was highest in those who used their bed cloths above one month $(77.78 \%)$, than those who used up to month (66.15\%). Those washed their bed cloths once in a week showed the lowest infestation rate (25\%). The children who washed their hair regularly with shampoo showed lowest prevalence were $40 \%$ and the children who did not use anything for washing hair, $85 \%$ were infested. Most of the family members (185) were suffering in pediculosis, and within family $91.89 \%$ child was infested. In above all cases results were statistically significant (Table 2). 
The number of straight hair children was 169 and of them $56.80 \%$ was infested with lice, whereas, 131 children have curly hair and the rate of infestation was $63.36 \%$. Here, hair type did not determine the lice infestation rate and statistical result showed not significant ( $\mathrm{p}>0.05)$ (Table-2).

Among 179 infested children, maximum 59.22\% children suffered for years, $17.88 \%$ for months, $12.85 \%$ for weeks and lowest number $10.05 \%$ was suffered for days (Table-3).

Among the infested children, 80 used anti lice shampoo (those are found in market, English anti-lice shampoo) and of them 22.5\% were cured and $77.5 \%$ children were not cured. It was stated that, at first time treatment of head lice, it reduces the number but not completely eradicated and later it becomes resistant to lice shampoo but remains under control with low infestation.

Head lice infestation is a public health problem among school children in both developed and developing countries (Ali and Ramzan 2004). Certainly, personal hygiene practices and socioeconomic status influence the level of prevalence (Zuhair et al. 2000). The present study, infestation rate was $59.67 \%$ which is attributed to the lower living standards and lack of awareness. In other different parts of the world, 59.7\% reported in Shillong, India (Roy and Tandon 1992), and 56.8\% in Argentina (Milano et al. 2007). However, much lower rate of infestation was recorded by 10.7-12.9\% in Malaysia (Sinniah et al.1981, 1983) and $12 \%$ in Saudi Arabia (Boyle 1987). These variations in infestation rate might be due to social status and personal hygiene practices of people and environmental factors.

Sarov et al. (2004), Suleman and Jabeen (2003) and Khokhar (2002) studied overcrowding condition of head lice infestation and among Primary school children in Delhi, Khokhar (2002) observed that those who shared both beddings and comb showed a statistically higher significance as compared to others. This may be, because the head lice can move freely from one person to another person through the use of same comb, dress and other materials of such nature. Ramusen (2004) who opined that, lice are spread more rapidly in large families living in crowded conditions, where bed-sharing and poor hygiene exist. Bathing (washing) factor was indirectly correlated with infestation as it was also observed by Schenonel and Lobos (1997) and Ali and Ramzan (2004). Maximum children suffered for years, and their hair becomes dull, cause skin infection and hair fall. The rate of cure by using anti lice shampoo was lower among the infested children because head lice become resistant after $2^{\text {nd }}$ and $3^{\text {rd }}$ time application of shampoo. In recent years resistance to insecticides have contributed to the increase of head lice prevalence (Nazari et al.2006).

This study provides some important factors of the epidemiology of pediculosis in a group of people in Bangladesh. The result of this study revealed that a clear relationship exist between the effectiveness of pediculosis and behavior of the children. This infestation is part of ignorance and unhygienic 
habits of children and mother. Parents need to involve themselves more in ensuring personal hygiene for their children. Pediculosis can be prevented by better personal hygiene and good environment condition. Infested children should be examined daily for 7 days. It is the best to treat everyone at the same time to avoid re-infection.

Table 1. Head lice infestation according to sharing and cleaning habits

\begin{tabular}{lcccccccc}
\hline Personal hygiene & Yes & $\begin{array}{c}\text { No. of } \\
\text { infeste } \\
\text { d child }\end{array}$ & $\begin{array}{c}\text { \% of } \\
\text { infested } \\
\text { child }\end{array}$ & $\begin{array}{c}\text { Do } \\
\text { not } \\
\text { share }\end{array}$ & $\begin{array}{c}\text { No. of } \\
\text { infeste } \\
\text { d child }\end{array}$ & $\begin{array}{c}\text { \% of } \\
\text { infested } \\
\text { child }\end{array}$ & $\boldsymbol{X}^{\mathbf{2}}$ & $\begin{array}{c}\text { p - } \\
\text { value }\end{array}$ \\
\hline $\begin{array}{l}\text { Habit of bed } \\
\text { sharing }\end{array}$ & 205 & 157 & 76.59 & 95 & 22 & 23.16 & 77.000 & 0.000 \\
$\begin{array}{l}\text { Habit of cloth } \\
\text { sharing }\end{array}$ & 170 & 142 & 83.53 & 130 & 37 & 28.46 & 92.826 & 0.000 \\
$\begin{array}{l}\text { Habit of towel } \\
\text { sharing }\end{array}$ & 217 & 168 & 77.42 & 83 & 11 & 13.25 & 102.715 & 0.000 \\
$\begin{array}{l}\text { Habit of comb } \\
\text { sharing }\end{array}$ & 230 & 171 & 74.35 & 70 & 8 & 11.43 & 88.283 & 0.000 \\
$\begin{array}{l}\text { Habit of bed } \\
\text { cleaning }\end{array}$ & 145 & 48 & 33.10 & 155 & 131 & 84.52 & 82.285 & 0.000 \\
$\begin{array}{l}\text { Habit of taking bath } \\
\text { regularly }\end{array}$ & 210 & 100 & 47.62 & 90 & 79 & 87.78 & 42.219 & 0.000 \\
$\begin{array}{l}\text { Habit of wearing } \\
\text { same cloth after }\end{array}$ & 180 & 145 & 80.56 & 120 & 34 & 28.33 & 81.592 & 0.000 \\
bath & & & & & & & & \\
\hline
\end{tabular}

Table 2. Head lice infestation according to overcrowding and washing habits

\begin{tabular}{lccccc}
\hline Characteristics & $\begin{array}{c}\text { No. of child } \\
\text { examined }\end{array}$ & $\begin{array}{c}\text { No. of infested } \\
\text { child }\end{array}$ & $\begin{array}{c}\text { Prevalence of } \\
\text { infested child }\end{array}$ & $\boldsymbol{X}^{\mathbf{2}}$ & $\begin{array}{c}\mathbf{p}- \\
\text { value }\end{array}$ \\
\hline $\begin{array}{l}\text { Overcrowding } \\
\text { condition- }\end{array}$ & & & & 71.808 & 0.000 \\
Yes & 188 & 147 & 78.19 & & \\
No & 112 & 32 & 28.57 & & \\
\hline Bed cloth washing- & & & & 39.506 & 0.000 \\
Once in a week & 60 & 15 & 25 & & \\
Once in a month & 195 & 129 & 66.15 & & \\
Above one month & 45 & 35 & 77.78 & & \\
\hline Hair washing with- & & & & 53.797 & 0.000 \\
Shampoo & 80 & 32 & 40 & & \\
Soap & 100 & 45 & 45 & & \\
Nothing & 120 & 102 & 85 & & \\
\hline Hair type- & & & & 1.317 & 0.217 \\
Straight & 169 & 96 & 56.80 & &
\end{tabular}




\begin{tabular}{lccccc}
\hline Characteristics & $\begin{array}{c}\text { No. of child } \\
\text { examined }\end{array}$ & $\begin{array}{c}\text { No. of infested Prevalence of } \\
\text { child }\end{array}$ & $\boldsymbol{X}^{\mathbf{2}}$ & $\begin{array}{c}\text { p - } \\
\text { infested child }\end{array}$ & \\
\hline Curly & 131 & 83 & 63.36 & & \\
\hline $\begin{array}{l}\text { Family members } \\
\text { suffering from }\end{array}$ & & & & 208.253 & 0.000 \\
pediculosis- & & & & & \\
Yes & 185 & 170 & 91.89 & & \\
No & 115 & 9 & 7.83 & & \\
\hline
\end{tabular}

Table 3. Head lice infestation on the basis of period of suffering of pediculosis

\begin{tabular}{lcc}
\hline \multicolumn{1}{c}{ Period of suffering } & $\begin{array}{c}\text { No. of suffering child among } \\
\text { 179 infested children }\end{array}$ & $\begin{array}{c}\text { \% of infested suffering } \\
\text { children }\end{array}$ \\
\hline Years & 106 & 59.22 \\
Months & 32 & 17.88 \\
Weeks & 23 & 12.85 \\
Days & 18 & 10.05 \\
\hline Total & 179 & 100 \\
\hline
\end{tabular}

\section{LITERATURE CITED}

ALI, N. and RAMZAN, F. 2004. Head lice infestation in school children at Dera Ismail Khan. Pakistan J. Zool. 36: 273-280.

BAILEY, A.M. and PROCIV, P. 2000. Persistent head lice following multiple treatments: evidence for insecticide resistance in Pediculus humanus capitis. Australas $J$. Dermatol. 41: 250-254.

BARTELS, C.L., PETERSON, K.E. and TAYLOR, K.L. 2001. Head lice resistance: itching that just won't stop. Ann Pharmacother. 35: 109-112.

BOYLE, P. 1987. Pilot study of the prevalence of head lice infestation in a population of Saudi Arabian children. FamPract. 4: 138-142.

HA, Y.C., HEO, J.M. and KIM, H.J. 2000. Infestation status of head louse and treatment with lindane shampoo in children of primary school and kindergarten in Chinju-shi, Kyongsangnam-do, Korea. Korean J. Parasitol. 38: 41-43.

KHOKHAR, A. 2002. A study of Pediculus capitis among primary school children in Delhi. Indian J. med. Sci. 56: 449-452.

KRASNOV, B., KHOKHLOVA, I. and SHENBROT, G. 2002. The effect of host density on ectoparasite distribution: An example of a rodent parasitized by fleas. Ecology. 83: 164-175.

LINARDI, P.M., BOTELHO, J.R. and MARIA, M. 1988. Crendices e falsos conceitos que dificultam ações profiláticas contra o piolho e a pediculose "capitis". J. Pediatria. 64: 248-255. 
MILANO, A.M.F., OSCHEROV, E.B. and LEGAL, A.Z. 2007. Pediculosis and other parasitosis in a northeast Argentine children population. Parasitologia Latinoamericana. 62 (1/2): 83-88.

MOSSONG, J., HENS, N., JIT, M., BEUTELS, P., AURANEN, K., MIKOLAJCZYK, R., MASSARI, M., SALMASO, S., TOMBA, G.S., WALLINGA, J., HEIJNE, J., SADKOWSKA-TODYS, M., ROSINSKA, M. and EDMUNDS, W.J. 2008. Social contacts and mixing patterns relevant to the spread of infectious diseases. PlosMedicin. 5: 381-391.

NAZARI, M., FAKOORZIBA, M.R. and SHOBEIRI, F. 2006. Pediculus capitis infestation according to sex and social factors in Hamedan, Iran. Southeast Asian J. Trop Med Public Health. 37(Suppl 3): 95-8.

RAMUSSEN, J.E. 2004. Pediculosis and the pediatrician. Pediatrics Dermatoloty. 6: 172177.

ROY, B. and TANDON, V. 1992. Louse infestation in human population in Shillong, India. Hlth. Hyg. 13: 15-20.

SAROV, B., NEUMAN, L. and HERMAN, Y. 2004. Evaluation of an intervention programme for head lice infestation in school children. Pediatrics Infestations Disease Journal. 12: 243-245.

SINNIAH, B., SINNIAH, D. and RAJESWARI, B. 1981. Epidemiology of Pediculus humanus capitis infestation in Malaysian school children. Am J. trop. Med. Hyg. 30: 734-738.

SINNIAH, B., SINNIAH, D. and RAJESWARI, B. 1983. Epidemiology and control of human head louse in Malaysia. Trop. Geogr. Med. 35: 337-342.

SOULTANA, V., EUTHUMIA, P., ANTONIOS, M., and ANGELIKI, R.S. 2009. Prevalence of pediculus capitis among school children in Greece and risk factors: A questionnaire survey. Pediatric Dermatology. 26: 701-705.

SLONKA, G.F., MCKINLEY, T.W., MCCROAN, J.E., SINCLAIR, S.P., SCHULTZ, M.G., HICKS, F. and HILL, N. 1976. Epidemiology of an outbreak of head lice in Georgia. The American Journal of Tropical Medicine and Hygiene. 25 (5): 739 -743.

SULEMAN, M. and JABEEN, N. 1989. Head lice infestation in some urban localities of NWFP, Pakistan. Annals of Tropical Medicine and Parasitology. 83: 539- 547.

WEGNER, Z., RACEWICZ, M. and STANCZAK, J. 1994. Occurrence of Pediculus capitis in a population of children from Gdansk, Sopot, Gdynia and the vicinities. Appl. Parasitology. 35: 219-225.

WILlEMS, S., LAPEERE, H., HAEDENS, N., PASTEELS, I., NAEYAERT, J.M. and DE, M.J. 2005. The importance of socio-economic status and individual characteristics on the prevalence of head lice in school children. Eur J. Dermatol. 15: 387-92.

ZUHAIR, S. and NUSIER, M.K. 2000. Pediculosis capitis in Northern Jordon. Int. J. Dermatol. 39: 919-921. 